\title{
NIE MA CIEMNOŚCI BEZ GWIAZDY - ZMAGANIA O NADZIEJĘ CZŁOWIEKA WSPÓŁCZESNEGO
}

„oto zmagam się z sobą samym

i zmagam się z tylu ludźmi o mą nadzieję"

(K. Wojtyła)

\section{Egzogenne predykatory stanu „bez-nadziei”}

Codzienne życie w postmodernistycznym świecie stawia przed człowiekiem szereg nowych wyzwań. Ponowoczesne społeczeństwo cechuje kultura mozaikowa - chaotyczna, bez wyraźnej hierarchii i punktów odniesienia ${ }^{1}$. Jest ona również związana z odrzuceniem szeroko rozumianych granic ${ }^{2}$. Coraz wyraźniej zarysowuje się też zjawisko określone jako „ludzka luka”, rozumiane jako swoisty dystans pomiędzy złożonością świata a zdolnością ludzi do sprostania jej3 ${ }^{3}$ Obecnie trudno jest zrozumieć człowiekowi znaczenie i następstwa tego, co czyni - zwłaszcza odnosząc się do szybkiego rozwoju techniki i cywilizacji. Człowiek nie potrafi wyjaśnić, przewidzieć powodowanych przez samego siebie zmian we własnym położeniu, tym samym bardziej oddala się od realnego świata. Co prawda rozwój nauki i techniki zapewnił mu władzę nad otoczeniem, jakiej dotychczas nigdy nie miał, jednak dynamiczność przemian, nadmiar informacji i bodźców powoduje poczucie powszechnej „niemożności” i zagubienia. Rodzi się również odczu-

Por. A. Molley, za: T. Żółkowska, Społeczna (de)waloryzacja roli osoby niepetnosprawnej, [w:] Człowiek z niepełnosprawnością w rezerwacie przestrzeni publicznej, red. Z. Gajdzica, Kraków 2013, s. 45.

2 Por. E. Budakowska, Wspótczesne migracje a nowe wyzwania, [w:] Tożsamość bez granic. Współczesne wyzwania, red. E. Budakowska, Warszawa 2005, s. 63.

3 Por. T. Hejnicka-Bezwińska, Pedagogika ogólna, Warszawa 2008, s. 177. 
cie trudności związane ze zrozumieniem i uporządkowaniem otaczającego świata przy jednoczesnym nasileniu potrzeby jego integracji ${ }^{4}$.

Problem ten dostrzegał także Jan Paweł II. Już na początku nowego tysiąclecia nakreślił niezbyt krzepiący obraz współczesności: „Wydaje się, że czasy, w jakich żyjemy i związane z nimi wyzwania to okres zagubienia. Tylu ludzi sprawia wrażenie, że są zdezorientowani, niepewni, pozbawieni nadziei [...] Obraz jutra jest często bezbarwny i niepewny. Bardziej się boimy przyszłości, niż jej pragniemy. Niepokojącą oznaką tego jest między innymi wewnętrzna pustka dręcząca wielu ludzi i utrata sensu życia. [...] Jesteśmy świadkami rozpowszechnionej fragmentaryzacji egzystencji; dominuje poczucie osamotnienia; mnożą się podziały i kontrasty. [...] Ludzie - choć nie brakuje im tego, co konieczne pod względem materialnym - czują się bardziej osamotnieni, pozostawieni samym sobie, pozbawieni uczuciowego oparcia"s. Warto postawić pytanie: Dlaczego niezaprzeczalny postęp, zdobycze techniki i nauki, wszystko, co ma służyć człowiekowi, stają się przyczyną jego zagubienia? Aby znaleźć rozwiązanie pogłębiającego się wciąż kryzysu trzeba - stwierdza Jan Paweł II - kreśląc sytuację człowieka w świecie współczesnym, zejść od zewnętrznych jej komponentów w immanentną prawdę człowieczeństwa ${ }^{6}$. Papież uważa, że przyczyna głębokich ludzkich niepokojów o własną tożsamość tkwi w nieadekwatnej wizji człowieka ${ }^{7}$. Rozwój cywilizacji materialistycznej narzuca hasła humanizmu ateistycznego, gdzie „bardziej mieć" dominuje nad „bardziej być”. Dlatego też w epoce, która choć szczyci się hasłami humanizmu i antropocentryzmu, człowiek niejednokrotnie poddaje się duchowi pesymizmu, beznadziejności czy nawet rozpaczy.

Osoba ludzka naturalnie dąży do szczęścia, jednak jeśli jego realizacja oparta jest na konsumpcjonizmie, szukaniu i zaspokajaniu doraźnych przyjemności, podporządkowywaniu się medialnie narzucanym modom, a unikaniu wysiłku i ofiary, to dążenie takie prowadzi do zniekształcania i zubażania istoty człowieczeństwa. Odrywając się od zasadniczego wymiaru ludzkiego życia - od Absolutu, człowiek skazuje się na degradację ${ }^{8}$. Pozbawiony transcendentnego znaczenia egzystencji, łatwo ulega gwałtownej namiętności, egoizmowi, okrucieństwu, anarchii zmysłów, wreszcie - zagładzie przez rozpacz 9 . Taka więc antropologia - bez Boga i bez Chrystusa - podkreśla Jan Paweł II - czyni człowieka absolutnym centrum rzeczywistości, każąc mu wbrew naturze rzeczy zająć miejsce Boga $^{10}$. Już w początkach pontyfikatu Jan Paweł II wskazywał, że rezygnacja czło-

\footnotetext{
4 Por. A. Kępiński, Poznaj siebie, Kraków 2003, s. 78.

Jan Paweł II, adhort. apost. Ecclesia in Europa, 7-8.

6 Por. tenże, enc. Redemptor hominis, 14.

7 Por. tenże, Mieć odwage proroków i ewangeliczna roztropność pasterzy, [w:] tegoż, $\mathrm{Na}$ uczanie papieskie [dalej: NP], t. II, 1 1979, Poznań 1990, s. 89.

8 Por. tamże.

9 Por. Jan Paweł II, Jezus - Słowo Wcielone głosi autentyczny sens życia, [w:] NP, t. IV, 2 1981, Poznań 1989, s. 325.

10 Por. tenże, adhort. apost. Ecclesia in Europa, 9.
} 
wieka ze swojego właściwego miejsca w świecie widzialnym i podporządkowanie się rzeczom, stosunkom ekonomicznym, czy wręcz stawanie się niewolnikiem produkcji, swoich własnych wytworów, nie tyko nie zaspokaja pragnienia szczęścia, ale wyzwala pogłębiający się lęk opanowujący ludzką egzystencję ${ }^{11}$. Dlatego - jak stwierdza Ojciec św. - „utrzymują się i nabierają ostrości niepokojące oznaki gaśnięcia nadziei” ${ }^{\prime 2}$.

\section{Posługa nadziei Jana Pawła II}

Papież nie poprzestaje tylko na diagnozie kondycji społeczeństw. Zna i wytrwale wskazuje drogi wyjścia z kryzysu. Przekonuje, że „aby odzyskać nadzieję i ufność u kresu tego stulecia cierpień, musimy na nowo objąć wzrokiem ów horyzont transcendentnych możliwości, ku któremu dąży ludzki duch"13. Jego wezwanie z dnia inauguracji pontyfikatu - „Nie lękajcie się” - zostało entuzjastycznie przyjęte przez współczesny świat, budząc przekonanie, że Jan Paweł II „będzie Papieżem odnowy chrześcijańskiej, a nadzieja, która od nas uciekła, razem z nim miała z powrotem pojawić się wśród nas" ${ }^{14}$. Jednak nie tylko chrześcijanie mieli być odbiorcami tego przesłania, jak też i całej posługi papieża. Po kilkunastu latach, komentując swoje pierwsze wystąpienie, stwierdzał: „W pewnym sensie było to wezwanie pod adresem wszystkich ludzi, wezwanie do przezwyciężenia lęku w globalnej sytuacji współczesnego świata. [...] Nie lękajcie się tego, coście sami stworzyli, nie lękajcie się świata tych wszystkich ludzkich wytworów, które coraz bardziej stają się dla człowieka zagrożeniem! Nie lękajcie się wreszcie siebie samych"15. Gdy stanął przed światowymi przywódcami na Forum Zgromadzenia Ogólnego ONZ chciał być postrzegany „jako świadek godności człowieka, świadek nadziei”'16 by wskazać jej siłę mogącą wyzwolić człowieka z lęku i przemienić świat. „Aby tysiąclecie stojące już u progu mogło być świadkiem nowego rozkwitu ludzkiego ducha, wspomaganego przez autentyczną kulturę wolności - mówił do przywódców państw - ludzkość musi się nauczyć przezwyciężać lęk. Musimy przestać się bać, odzyskując ducha nadziei i ufności"17. Każda istota ludzka potrzebuje do rozwoju, życia i szczęścia, konkretnych perspektyw na przyszłość. „Człowiek - stwierdza Ojciec św. - nie może żyć bez nadziei. Musi do czegoś dą-

\footnotetext{
11 Por. tenże, enc. Redemptor hominis, 15-16.

12 Tenże, adhort. apost. Ecclesia in Europa, 10.

13 Tenże, Przemówienie do Zgromadzenia Ogólnego ONZ, [w:] Przemówienia i homilie Ojca Świętego Jana Pawła II, Kraków 2008, s. 54.

14 A. Frossard, Nie lękajcie się! Rozmowy z Janem Pawłem II, Watykan 1982, s. 8.

15 Jan Paweł II, Przekroczyć próg nadziei. Jan Paweł II odpowiada na pytania Vittoria Messoriego, Lublin 1994, s. 160.

16 Tenże, Przemówienie do Zgromadzenia Ogólnego ONZ, dz. cyt., s. 55.

17 Tamże, s. 54.
} 
żyć, musi mieć w życiu cel oraz poczucie, że zdoła go osiągnące"18. Cała ludzkość i każdy człowiek z osobna niejednokrotnie już doświadczyli iluzji swoich nadziei, które będąc w rzeczywistości ucieczką od prawdy i trudu życia, owocowały bólem rozczarowania, poczuciem beznadziejności. Im powszechniejsze są pokusy zwątpienia i doświadczenie porażki, tym konieczniejsze jest odnalezienie prawdziwego źródła nadziei. Poeta - K. Wojtyła wskazał je słowami poematu: „mej nadziei nie potwierdza we mnie/ żadne złoże własnej tylko pamięci,/ nadziei w zwierciadle mijania nie odtwarza nic,/ tylko Twoje Przejście paschalne/ zespolone z zapisem najgłębszym mego bytu"19, a na Forum ONZ, już jako Jan Paweł II, wyznaje wprost: „Jako chrześcijanin muszę też dać świadectwo, że fundamentem mojej nadziei i ufności jest Jezus Chrystus” [...], w którego „śmierci i zmartwychwstaniu została w pełni objawiona miłość Boga i Jego troska o całe stworzenie" ${ }^{\text {"20. Nadzieja }}$ oparta na takim fundamencie jest dostępna dla każdego człowieka, nie tylko dla chrześcijan. Jezus bowiem, mimo iż człowiek go świadomie nie wybiera czy nawet deklaruje ateizm, jest nienazwanym celem dla każdego, kto dąży do prawdziwych i nieprzemijających wartości. „W rzeczywistości, kiedy marzycie o szczęściu, szukacie Jezusa - przekonuje Jan Paweł II - to On na was czeka, gdy nie zadowala was nic z tego, co znajdujecie. To On jest pięknem, które tak was pociąga. To On wzbudza $\mathrm{w}$ was pragnienie radykalnych wyborów [...]. To Jezus wzbudza w was pragnienie, byście uczynili ze swego życia coś wielkiego [...]. Daje odwagę, by pokornie i wytrwale dążyć do doskonalenia samych siebie i społeczeństwa"21. Należy mocno podkreślić, że nadzieja niezachwiana i pełna realizmu, wznoszona na fundamencie Osoby Jezusa jest postawą zaangażowania, odpowiedzialności, męstwa i hartu wewnętrznego. Wezwaniem - „nie lękajcie się” - papież nie sugeruje bezpodstawnego optymizmu, braku poczucia odpowiedzialności. Stwierdza natomiast, że powtarzając te słowa Chrystusa, wraz z Nim „potwierdza całą prawdę Ewangelii i wszystkie wymagania w niej zawarte". Równocześnie ujawnia, że wymagania te nie są ponad miarę możliwości człowieka, który przyjmując je w duchu wiary, znajduje „tajemnicze siły do tego, aby im sprostać" 22 . Nadzieja więc „nie jest pobożnym życzeniem, czy niejasnym uczuciem”23 - stwierdza papież. Nie jest też „próżnym optymizmem, podyktowanym przez naiwne przekonanie, że przyszłość będzie na pewno lepsza niż przeszłość" ${ }^{24}$. Nadzieja - wskazuje papież - „mieszcząc w sobie psychologiczną skłonność duszy do trudno osiągalnego dobra, jest postawą typową dla «homo viator» - człowieka pielgrzyma, który

18 Jan Paweł II, Nadzieja - kryterium zmian i rozwoju, „L'Osservatore Romano” $1980 \mathrm{nr}$ 8, s. 9.

19 Tenże, Rozważanie o śmierci, [w:] Posłaniec Miłości, Warszawa-Rzeszów 2005, s. 135.

20 Tenże, Przemówienie do Zgromadzenia Ogólnego ONZ, dz. cyt., s. 54.

${ }^{21}$ Tenże, Przemówienie w czasie XV ŚDM, Rzym, 19 sierpnia 2000, [w:] Przemówienia i homilie..., dz. cyt., s. 643.

22 Por. tenże, Przekroczyć próg nadziei, dz. cyt., s. 163.

23 Tenże, Nadzieja - kryterium zmian i rozwoju, dz. cyt., s. 9.

24 Tenże, Przemówienie do Zgromadzenia Ogólnego ONZ, dz. cyt., s. 54. 
ma świadomość, że swój cel w pełni osiągnie w eschatologicznym spełnieniu”25. Postawa nadziei, ukierunkowując człowieka na wieczność, nie odrywa go od doczesności. Nie jest biernym oczekiwaniem dóbr przyszłych, lecz postawą zaangażowania, dzięki której „tu i teraz” z wytrwałością i stałością człowiek wypracowuje to, co w nadziei zamierza osiągnąć ${ }^{26}$. Mimo więc, że nadzieja sięga przyszłości, równocześnie określa duchowy stan człowieka w teraźniejszości. Wskazując wartość, jaką pragnie on osiągnąć, uwypukla wartość, jaką chce on nadać swojemu życiu. Nadzieja człowieka wyraża więc zasadnicze poczucie sensu jego życia $^{27}$. W tym aspekcie może zatem być nie tylko „lekarstwem” na ludzkie lęki, niepokoje i pokusy rozpaczy, ale także „lekarstwem” korygującym i uzdrawiającym doczesne nadzieje $\mathrm{e}^{28}$. To właśnie nadzieja zwraca człowieka do Boga jako celu. Najgłębszym jej wymiarem jest nie tyle oczekiwanie na coś, ile relacja międzyosobowa - taki rodzaj przyjaźni, solidarności i współdziałania, który prowadzi do zawierzenia i powierzenia siebie Chrystusowi ${ }^{29}$. Odniesienie osoby ludzkiej do Osoby Jezusa Chrystusa sprawia, że nadzieja wyzwala człowieka z bezideowości i bezsensu życia - przez gotowość chcenia tego, czego chce sam Bóg - oraz z rozpaczy - dzięki zawierzeniu ${ }^{30}$. Tak więc kto żyje nadzieją, może niejednokrotnie doświadczyć samotności, rozczarowań, różnorodnych przeszkód i zagrożeń, ale znając źródło swojej mocy, nie ulegnie rozpaczy. Sytuacje trudne są najlepszym sprawdzianem prawdziwości i siły nadziei. Jan Paweł II, wskazując na jej wartość i moc, którą wnosi ona w życie każdego człowieka i całych społeczeństw, przekonuje, że ,jest rzeczą bardzo ważną, ażeby przekroczyć próg nadziei, nie zatrzymywać się przed nim, ale pozwolić się prowadzić”31.

\section{Patologiczny stan braku nadziei}

Nierzadko zdarzają się sytuacje, w których człowiek nie potrafi przekroczyć wspomnianego „progu nadziei” i w ogólnym chaosie - zarówno wewnętrznym, jak i zewnętrznym - poddaje się uczuciom lęku, niepokoju czy nieokreślonych tęsknot ${ }^{32}$. Przy tak zarysowanym kontekście społecznym nie dziwią statystyki wskazujące na rosnący problem zachorowalności na depresję. Szacuje się, że występuje ona o różnym nasileniu u 12-25 proc. pacjentów zgłaszających się do le-

25 Tenże, Wierzę w Ducha Świętego, Watykan 1992, s. 387.

26 Por. tenże, List do młodych całego świata Parati semper, 1.

27 Por. tenże, Nadzieja - kryterium zmian i rozwoju, dz. cyt., s. 9.

28 Por. J. Nagórny, Nadzieja chrześcijańska wobec wyzwań współczesności, [w:] Nadzieja chrześcijańska a nadzieje ludzkie, red. J. Nagórny, M. Pokrywka, Lublin 2003, s. 75.

29 Por. tamże, s. 77.

30 Por. Jan Paweł II, Jestem bardzo w rękach Bożych. Notatki osobiste 1962-2003, Kraków 2014, s. 58.

31 Tenże, Przekroczyć próg nadziei, dz. cyt., s. 163.

32 Por. A. Kępiński, Poznaj siebie, dz. cyt., s. 83. 
karza pierwszego kontaktu, z czego 6-10 proc. to przypadki o nasileniu umiarkowanym lub ciężkim ${ }^{33}$. Należy zauważyć, że choć termin „depresja”, często nadużywany w języku potocznym - traktowany jako synonim smutku - medycznie stanowi określenie wielu objawów psychopatologicznych, z których obniżenie nastroju jest jedynie jednym z symptomów jej występowania. Pojęcie depresji obejmuje różne stany chorobowe, mniej lub bardziej głębokie czy trwałe. Przeważnie konieczna jest fachowa pomoc psychiatryczna i leczenie farmakologiczne. Często proponuje się formę psychoterapii ${ }^{34}$. Chorobie tej towarzyszy lęk, zaburzenia rytmu biologicznego, izolacja i wiele innych czynników, których nie sposób w tym miejscu wymienić i opisać ${ }^{35}$. Warto jednak podkreślić, że depresja stanowi patologiczny stan „bez-nadziei” człowieka, któremu należy skutecznie przeciwdziałać.

Coraz powszechniejsze występowanie stanów depresyjnych u ludzi, budziło również niepokój Jana Pawła II, dlatego też znalazł się wśród tych, którzy szukają drogi do zapewnienia właściwej opieki chorym i skutecznej formy działalności wspierającej ich rodziny. Swoją propozycję „terapii” przedstawił w ramach spotkania z uczestnikami międzynarodowej konferencji na temat: „Depresja chorobą naszych czasów”, wskazując drogi wyjścia z kryzysu egzystencjalnego i duchowego.

Trzeba pamiętać, że choroba ta ogarnia całego człowieka - nie tylko jego ciało i psychikę. Ojciec św. przypomina, że depresja jest zawsze doświadczeniem duchowym $^{36}$. Dlatego też udzielając choremu pomocy, należy uwzględnić i tę płaszczyznę. Skuteczność podejmowanych form pomocy ukierunkowanych na sferę psychosomatyczną szacuje się na ok. 50 proc. $^{37}$. Ich uzupełnienie można odnaleźć we wskazaniach kreślonych przez Ojca św.

Jaką więc drogę wyzwolenia z paraliżującego lęku, pustki i bezsensu proponuje chorym i ich otoczeniu Jan Paweł II? Jest to „terapia duchowa”, polegająca na umacnianiu i pogłębianiu życia duchowego oraz uczynienia Chrystusa fundamentem swojej egzystencji. Papież pragnie, aby każdy człowiek w Nim znalazł klucz do szczęścia, poczucia sensu i wartości swojej osoby i swojego życia. „Człowieka bowiem nie można do końca zrozumieć bez Chrystusa - przekonuje Jan Paweł II. - A raczej: człowiek nie może siebie sam do końca zrozumieć bez Chrystusa. Nie może zrozumieć ani kim jest, ani jaka jest jego właściwa godność,

33 Por. M. Siwek, Diagnostyka i psychopatologia depresji, [w:] XXXI Zimowa Szkoła Instytutu Farmakologii PAN. Streszczenie wykładów, red. M. Papp, Kraków 2014, s. 2.

34 Więcej: J. Heitzman, N. Wojnar, Zaburzenia i choroby afektywne, [w:] Psychiatria, J. Heitzman, Warszawa 2007, s. 109-119.

35 Por. tamże, s. 112-113.

36 Por. Jan Paweł II, Jak pomagać ludziom cierpiącym na depresję? Do uczestników międzynarodowej konferencji Papieskiej Rady ds. Duszpasterstwa Służby Zdrowia, 14.11.2003, 3, „L'Osservatore Romano” 2004 nr 3, s. 28.

37 Por. D. Dudek, Leczenie depresji, [w:] XXXI Zimowa Szkoła Instytutu Farmakologii PAN, dz. cyt., s. 5. 
ani jakie jest jego powołanie i ostateczne przeznaczenie" ${ }^{38}$. Tylko Chrystus może otworzyć człowiekowi przestrzenie nadziei, jako życiowej siły.

\section{Wskazania dla praktyki terapeutycznej}

Podkreślmy raz jeszcze: „Terapia ducha” - którą poleca Jan Paweł II - nie wyklucza fachowej opieki i pomocy medycznej, lecz stanowi jej uzupełnienie. Jest środkiem „wspomagającym”, który niejednokrotnie przy początkowych symptomach choroby lub łagodnych stanach depresyjnych może okazać się skutecznym i wystarczającym ,lekiem”.

Pierwszym etapem rozpoczynającym „terapię duchową” jest konieczność poznania przyczyn stanów depresyjnych, tak by znaleźć na nie stosowne lekarstwo, podobnie jak w przypadku terapii medycznej i psychologicznej ${ }^{39}$. Następnie papież w tym kontekście sugeruje, że „trzeba sobie koniecznie uświadomić, jaki wpływ mają na ludzi treści szerzone przez środki przekazu, które głoszą pochwałę konsumpcjonizmu, wzywają do natychmiastowego zaspokajania pragnień, do zabiegania o coraz większy dobrobyt materialny" ${ }^{40}$. Jest on zdecydowanie destruktywny! Jan Paweł II zaleca więc, by „proponować nowe wartości, ażeby każdy mógł budować swoją osobowość, rozwijając życie duchowe, które jest fundamentem dojrzałej egzystencji” ${ }^{41}$. Uważa, że „bardzo ważnym zadaniem jest wskazywanie ludziom, zwłaszcza młodym, wzorców osobowych oraz proponowanie określonych praktyk, które pomogą im wzrastać na płaszczyźnie ludzkiej, psychicznej, moralnej i duchowej. Brak takich punktów odniesienia z pewnością przyczynia się do osłabienia struktury osobowości, prowadzi bowiem do przekonania, że wszystkie rodzaje zachowań zasługują na taką samą ocenę"42.

Jan Paweł II, wskazując na zasadniczą rolę rodziny, szkoły, ruchów młodzieżowych, stowarzyszeń parafialnych w formacji osoby, przypomniał naukę Soboru: „Słusznie możemy sądzić, że przyszły los ludzkości leży w ręku tych, którzy potrafią podać następnym pokoleniom motywy życia i nadziei” ${ }^{43}$. Sam dawał świadectwo wykorzystania każdego wystąpienia, by proponować prawdziwe wartości, by wskazywać Tego, którego obecność i pomoc w ludzkiej codzienności jest w stanie przekonać, że warto żyć i dążyć do osiągnięcia szczęścia i radości na drodze daru z siebie. Szczególną okazją ku temu były Światowe Dni Młodzieży, dzięki którym przesłanie papieża docierało do młodych całego świata i było przez nich entuzjastycznie przyjmowane. Przesłanki dotyczące wartości życia samego w sobie

\footnotetext{
38 Jan Paweł II, Pielgrzymka Jana Pawła II do Polski, Poznań-Warszawa 1979, s. 22.

39 Więcej: D. Dudek, Leczenie depresji, dz. cyt. s. 4-6; J. Heitzman, N. Wojnar, Zaburzenia $i$ choroby afektywne, dz. cyt., s. 109-121.

40 Jan Paweł II, Jak pomagać ludziom..., dz. cyt., 2.

41 Tamże.

42 Jan Paweł II, Jak pomagać ludziom..., dz. cyt., 4.

43 KDK 31, za: Jan Paweł II, Trzecia pielgrzymka do Polski, Paryż 1987, s. 24.
} 
są istotne zwłaszcza dla osób chorujących na depresję, u których przewlekłe zaburzenia nastroju zawsze pociągają za sobą ryzyko popełnienia samobójstwa ${ }^{44}$.

W swoim „programie przeciw depresji” Ojciec św. podkreśla też rolę instytucji publicznych, które zobowiązane są zapewnić godziwe warunki egzystencji, zwłaszcza ludziom opuszczonym, chorym i starszym, umacniając w nich poczucie własnej wartości i sensowności życia. Zachęca do tworzenia odpowiednich programów politycznych, które wskazując nowym pokoleniom motywy nadziei, chroniłyby je przed pustką i takimi próbami jej wypełnienia, które mogą okazać się niebezpieczne ${ }^{45}$.

Kolejnym kręgiem osób, które Jan Paweł II włącza w działania mające na celu przywrócić nadzieję i wartość życia osobom w depresji, są ludzie opiekujący się chorymi - ich najbliższe otoczenie. Papież uważa, że „powinni przede wszystkim dopomagać im w odzyskaniu szacunku dla samych siebie, wiary we własne umiejętności, zainteresowania przyszłością i woli życia"46. Zadanie to z pewnością jest trudne i wymagające prawdziwej miłości wobec osoby chorej, tej miłości, która „cierpliwa jest, nie szuka poklasku, wszystko znosi i wszystko przetrzyma” (por. 1 Kor 13). Konieczne też wydaje się, aby w życiu wspierającego otoczenia nie brakowało prawdziwej nadziei, budowanej na relacji „osoby do Osoby”, gdyż tylko „człowiek, który czuwa i wyczekuje spełnienia się obietnic Chrystusa, potrafi natchnąc nadzieją także swoich braci i siostry, często zniechęconych i pesymistycznie patrzących w przyszłość" ${ }^{\prime \prime 7}$. Najskuteczniejszą formą wyciągnięcia do chorych pomocnej dłoni jest: „pozwolić im odczuć dobroć Boga, włączyć ich we wspólnotę wiary i życia, w której mogliby czuć się akceptowani, rozumiani, wspomagani; w której - jednym słowem - czuliby się godni, aby kochać i być kochanymi" ${ }^{4}$. Wyrazi się to przede wszystkim w obecności przy nich i z nimi, wysłuchaniu, poprowadzeniu dialogu, okazaniu współczucia oraz konkretnej pomocy ${ }^{49}$. „Miłość jest najdoskonalszym świadectwem, które otwiera człowieka na nadzieję" - zaświadcza Ojciec św., a wypływająca z niej służba wnosi sens nie tylko w życie tych, którzy są jej odbiorcami. Czyni pięknym i wartościowym również życie tych, którzy wydają się być jej dawcami ${ }^{50}$.

Wreszcie pewne działania proponuje Ojciec św. tym, którzy ulegli depresji, a są na tyle samodzielni, że można ich motywować i zachęcać do wysiłku psychicznego i duchowego. Samo zażywanie leków nie rozwiąże całkowicie problemów ludzi chorych na depresję. Każda z osób motywujących, wyznaczających konkretne zadania, powinna „zdawać sobie sprawę, ile trudu kosztuje osoby cierpiące

\footnotetext{
44 Por. P. D. Kramer, Czym jest depresja, Poznań 2007, s. 24.

45 Por. Jan Paweł II, Jak pomagać ludziom..., dz. cyt., 4.

46 Tamże, 3.

47 Jan Paweł II, adhort. apost. Vita consecrata, 27.

48 Tenże, Jak pomagać ludziom..., dz. cyt., 3.

49 Por. tenże, adhort. apost. Christifideles laici, 54.

50 Por. tenże, Tekst przemówienia papieskiego przekazany młodzieży do refleksji. Paryż - Pola Marsowe 1997, [w:] Przemówienia i homilie, dz. cyt., s. 313.
} 
na depresję to, co innym wydaje się proste i naturalne - ostrzega Jan Paweł II, i radzi - „trzeba dopomagać im cierpliwie i delikatnie, zgodnie z napomnieniem św. Teresy od Dzieciątka Jezus: Mali stawiaja małe kroki" ${ }^{51}$.

Podstawowym doświadczeniem, które otwiera na nadzieję i przynagla do wyboru życia - jak zauważa papież - jest „dla nich, jak dla każdego, kontemplacja Chrystusa i zarazem przyzwolenie, aby On na nich patrzył" ${ }^{2}$. Szczególnie wtedy, gdy nachodzą ciemności bezsensu, pustki, warto zwrócić spojrzenie na Chrystusa. „Tylko On jest światłem prawdziwym, które oświeca każdego człowieka [...] Jedynie Jezus może nas oświecić w sposób całkowity co do problemu życia i historii”"53. Jest On w stanie obdarzyć mocą, która pozwoli przetrwać najtrudniejsze chwile w życiu. „Mocna wiara, z której rodzi się nadzieja - stwierdza Ojciec św. - uwalnia człowieka od lęku i daje mu siłę duchową do przetrwania wszystkich burz życiowych”. I zachęca - „Nie lękajcie się Chrystusa! Zaufajcie Mu do końca! On jedyny «ma słowa życia wiecznego». Chrystus nie zawodzi” ${ }^{54}$. Kontemplacja Chrystusa pozwala zbliżyć się do najbardziej paradoksalnego aspektu tajemnicy Boga-Człowieka i odkryć Jego cierpiące Oblicze ${ }^{55}$, a w ten sposób dostrzec Miłość, która jest „największa”, która wyraziła się przez krzyż, a bez której życie ludzkie nie ma ani korzenia, ani sensu ${ }^{56}$. Krzyż i cierpienie nie są jednak finałem dialogu z Chrystusem. Nie należy zatrzymywać się na wizerunku Ukrzyżowanego - Chrystus jest Zmartwychwstałym ${ }^{57}$. Krzyż zwieńczony zmartwychwstaniem niesie człowiekowi uwikłanemu w trudności i problemy, po ludzku nie do rozwiązania, prawdziwą nadzieję. Pomaga zobaczyć na nowo perspektywę swego losu, uczy dostrzegać swoją godność i mierzyć ją miarą tej Ofiary, jaką dla jego zbawienia Bóg złożył ze swojego Syna ${ }^{58}$. Niesie umacniające przesłanie: „nie ma rozbicia bez nadziei - ciemności bez gwiazdy - burzy bez bezpiecznej przystani"59.

Kolejną proponowaną przez Jana Pawła II formą pogłębienia życia duchowego osób doświadczających stanów depresyjnych może być lektura i rozważanie Psalmów, w których natchniony autor wyraża w modlitwie swoje radości i lęki ${ }^{60}$. Jest to okazja, aby własne trudne doświadczenia zobaczyć w horyzoncie doświadczeń innych, którzy szukając pomocy Bożej, potrafili wyjść z nich zwycięsko.

Ważnym czynnikiem wzmacniającym siły duchowe jest również w przekonaniu Jana Pawła II odmawianie różańca, dzięki któremu chory może odnaleźć

${ }^{51}$ Tenże, Jak pomagać ludziom ..., dz. cyt., 3.

52 Tamże.

53 Jan Paweł II, Jezus - Słowo Wcielone głosi autentyczny sens życia, [w:] NP, t. IV, 2 1981, dz. cyt., s. 325.

54 Tenże, V pielgrzymka Jana Pawła II do Ojczyzny, Sandomierz 1997, s. 67.

55 Por. tenże, list apost. Novo millennio ineunte, 25.

56 Por. tenże, Pielgrzymka Jana Pawła II do Polski, dz. cyt., s. 211.

57 Por. tenże, list apost. Novo millennio ineunte, 28.

58 Por. tenże, Pielgrzymka Jana Pawła II do Polski, dz. cyt., s. 192.

59 Tenże, Krzyż Zbawiciela, Kraków 2010, s. 87.

60 Tenże, Jak pomagać ludziom ..., dz. cyt., 3. 
w Maryi miłującą Matkę, uczącą żyć w Chrystusie ${ }^{61}$. Różaniec jest modlitwą, którą on sam bardzo ukochał. Modlitwą - jak mówił - przedziwną w swojej prostocie i głębi zarazem ${ }^{62}$. Stwierdzał, że „przez różaniec człowiek niejako „wstępuje do szkoły Maryi, dając się wprowadzić w kontemplację piękna Oblicza Chrystusa i w doświadczanie głębi Jego miłości” ${ }^{33}$. Człowiek, dostrzegając miłość objawiającą się nie tyko w radościach, ale też w boleści i smutku, potrafi w tej perspektywie spojrzeć na swoje życie przeniknięte smutkiem, lękiem czy bezsilnością, zyskując nową moc. Papież, pragnąc zachęcić wielu do korzystania z tej pomocy, wyznaje: „Różaniec towarzyszył mi w chwilach radości i doświadczenia. Zawierzyłem mu wiele trosk. Dzięki niemu zawsze doznawałem otuchy" ${ }^{64}$.

Kolejnym momentem dającym siłę i chęć życia jest - Eucharystia, gdyż „udział w Eucharystii - naucza Jan Paweł II - jest źródłem wewnętrznego pokoju, zarówno dzięki działaniu Słowa i Chleba życia, jak i przez uczestnictwo we wspólnocie kościelnej”ㄷ․ Jak wielką siłę oferuje w Eucharystii stół Słowa, wykazuje Ojciec św., przypominając ewangelicznych uczniów z Emaus, w których słowa Chrystusa wywołują „poruszenie” serc, chronią ich przed mrokiem smutku i rozpaczy, wzbudzają pragnienie pozostania z Nim${ }^{66}$. Stół Chleba, stół uczty o wymiarze ofiarniczym, to - przekonuje Ojciec św. - najcenniejszy Chrystusowy dar na drogach historii, gdyż jest to dar z samego siebie. Wydarzenia paschalne - śmierć i zmartwychwstanie uobecniają miłość bez miary - „do końca” ${ }^{67}$. Przez tę miłość i przez sakrament, który tę miłość wyraża, Chrystus daje od wewnątrz najpotężniejszy środek „siły przebicia”, która jest potrzebna, aby przedwcześnie się nie wycofać, nie uciec, nie załamać, nie zgubić perspektywy ${ }^{68}$. Udział w Eucharystii powinien umacniać świadomość: „Jestem miłowany. Ja, taki jaki jestem. Każdy w swoim najbardziej indywidualnym człowieczeństwie" - przypomina Ojciec św., i konkluduje - „Jeżeli mnie ktoś miłuje, jestem silny"69.

Czynnikiem wspomagającym chęć i wolę życia osoby chorej na depresję będzie więc z pewnością obudzenie świadomości, że „W swej nieskończonej miłości Bóg jest zawsze blisko tych, którzy cierpią" - zapewnia Ojciec św., a „depresja może być drogą do odkrycia nowych aspektów własnej osobowości oraz nowych form spotkania z Bogiem"70. Choć praktyka psychologów i psychiatrów wskazuje, że choroba ta pozostawia trwały ślad w życiu człowieka i ,żaden pacjent - pod-

61 Por. tamże.

62 Por. Jan Paweł II, Modlitwa, którą bardzo ukochałem, [w:] NP, t. I 1978, Poznań-Warszawa 1987, s. 22.

${ }_{63}$ Tenże, list apost. Rosarium Virginis Mariae, 1.

64 Tamże, 2.

65 Por. Jan Paweł II, Jak pomagać ludziom..., dz. cyt., 3.

66 Por. tenże, list apost. Mane nobiscum Domine, 12.

67 Por. tenże, enc. Ecclesia de Eucharistia, 9, 11.

68 Por. tenże, Trzecia pielgrzymka do Polski, dz. cyt., s. 79-80.

69 Tamże, s. 81.

70 Jan Paweł II, Jak pomagać..., dz. cyt., 3. 
kreśla jeden z psychiatrów zajmujący się tym zaburzeniem - dotknięty silną depresją po wyzdrowieniu nie powiedział o niej ani jednego życzliwego słowa" ${ }^{\prime \prime 1}$, to jednak Jan Paweł II zachęca: „Proszę was - abyście mieli ufność nawet wbrew każdej swojej słabości, abyście szukali zawsze duchowej mocy u Tego, u którego tyle pokoleń ojców i matek ją znajdowało"72.

\section{Podsumowanie: 9 kroków ku nadziei}

W niniejszym opracowaniu starano się nakreślić podstawowy rys nauczania Jana Pawła II o nadziei, przedstawiając go w kontekście współczesnej sytuacji społecznej i ogólnej kondycji psychicznej człowieka. Niezwykła przenikliwość myśli świętego już papieża zdumiewa aktualnością i rzeczowością wskazań. Apostoł nadziei i miłosierdzia Bożego wychodzi naprzeciw tym, którzy w walce o odnalezienie swojej tożsamości w świecie upadają pod ciężarem zadań dnia codziennego. Podkreśla, że „(Chrystus) nie przestaje człowiekowi znużonemu, zagubionemu, człowiekowi, który cierpi, który gubi poczucie sensu - przywracać sens"73. Wskazania Jana Pawła II są aktualne dla każdego człowieka, którego walka o nadzieję i sens życia mieści się w szeroko rozumianej normie, jak również dla tych, którzy cierpią na depresję. Myśląc szczególnie o tej grupie osób, Ojciec św. wyznacza dziewięć zadań, które należy podjąć, aby odzyskać nadzieję. Pięć z nich odnosi się do najbliższego otoczenia chorego. Powtórzmy, są to:

- diagnoza aktualnego stanu rzeczy - rozpoznanie przyczyn utraty nadziei,

- wskazanie wartości - szczególne zadanie dla rodzin, szkół i innych instytucji znaczących,

- zapewnienie bezpieczeństwa i godziwych warunków życia - zadanie dla instytucji życia publicznego,

- okazywanie miłości i cierpliwości choremu,

- stworzenie warunków doświadczenia dobroci Boga.

Cztery kolejne stanowią wyzwanie dla osoby chorującej:

- kontemplacja ukrzyżowanego i uwielbionego Oblicza Chrystusa,

- rozważanie psalmów,

- modlitwa różańcowa,

- Eucharystia.

Odzyskanie czy też utrzymanie nadziei stanowi szczególne zadanie współczesnego świata, dla którego poczucie lęku wydaje się być stałym komponentem jego struktury. Uwolnienie z lęku jest jednak możliwe tylko wtedy, gdy buduje się na

$71 \quad$ P. D. Kramer, Czym jest depresja, dz. cyt., s. 21.

72 Jan Paweł II, Homilia podczas uroczystej Mszy św. ku czci św. Stanisława, dz. cyt., s. 211.

73 Tenże, Trzecia pielgrzymka do Polski, dz. cyt., s. 12. 
nadziei. To ona pomaga znosić i przetrzymać przykrości. Tam, gdzie zanika, tam też zanika człowiek ${ }^{74}$.

Kończąc, warto podkreślić, że „plan terapeutyczny” Jana Pawła II nie zapewni natychmiastowych efektów, jednak konsekwentnie i z wiarą realizowany pozwoli w społeczeństwie płynnym i zmiennym ukształtować perspektywę życia ukierunkowanego na nieprzemijające wartości, gdyż „dla chrześcijanina sytuacja nigdy nie jest beznadziejna. Chrześcijanin jest człowiekiem nadziei"75.

\section{Bibliografia}

Jan Paweł II, Encyklika Ecclesia de Eucharistia, Katowice 2003.

Jan Paweł II, Encyklika Redemptor hominis, Poznań 1979.

Jan Paweł II, Adhortacja apostolska Christifideles laici, Watykan 1998.

Jan Paweł II, Adhortacja apostolska Ecclesia in Europa, „L'Osservatore Romano” 2003 nr 7-8.

Jan Paweł II, Adhortacja apostolska Vita consecrata, Katowice 1996.

Jan Paweł II, List apostolski Mane nobiscum Domine, Katowice 2004.

Jan Paweł II, List apostolski Novo millennio ineunte, Wrocław 2001.

Jan Paweł II, List do młodych całego świata Parati semper, [w:] Jan Paweł II do młodzieży, Poznań 2005.

Jan Paweł II, List apostolski Rosarium Virginis Mariae, Katowice 2002.

Jan Paweł II, Jak pomagać ludziom cierpiącym na depresję?, „L'Osservatore Romano” 2004 nr 3. Jan Paweł II, Jestem bardzo w rękach Bożych. Notatki osobiste 1962-2003, Kraków 2014.

Jan Paweł II, Jezus - Słowo Wcielone głosi autentyczny sens życia, [w:] Jan Paweł II, Nauczanie papieskie, t. IV, 2 1981, Poznań 1989.

Jan Paweł II, Krzyż Zbawiciela, Kraków 2010.

Jan Paweł II, Mieć odwage proroków i ewangeliczna roztropność pasterzy, [w:] Jan Paweł II, Nauczanie papieskie, t. II, 1 1979, Poznań 1990.

Jan Paweł II, Modlitwa, która bardzo ukochałem, [w:] Jan Paweł II, Nauczanie papieskie, t. I 1978, Poznań-Warszawa 1987.

Jan Paweł II, Nadzieja - kryterium zmian i rozwoju, „L'Osservatore Romano” 1980 nr 8.

Jan Paweł II, Pielgrzymka Jana Pawła II do Polski, Poznań-Warszawa 1979.

Jan Paweł II, Posłaniec Miłości, Warszawa-Rzeszów 2005.

Jan Paweł II, Przekroczyć próg nadziei, Lublin 1994.

Jan Paweł II, Przemówienie do Zgromadzenia Ogólnego ONZ, [w:] Przemówienia i homilie Ojca świętego Jana Pawła II, Kraków 2008.

Jan Paweł II, Tekst przemówienia papieskiego przekazany młodzieży do refleksji. Paryż - Po-

la Marsowe 1997, [w:] Przemówienia i homilie Ojca świętego Jana Pawła II, Kraków 2008. Jan Paweł II, Trzecia pielgrzymka do Polski, Paryż 1987.

74 Por. A. J. Nowak, Psychologiczny aspekt nadziei, [w:] Nadzieja w postawie ludzkiej, red. W. Słomka, Lublin 1992, s. 86 (Homo Meditans, 7).

75 Jan Paweł II, Trzecia pielgrzymka do Polski, dz. cyt., s. 119. 
Jan Paweł II, V pielgrzymka Jana Pawła II do Ojczyzny, Sandomierz 1997.

Jan Paweł II, Wierzę w Ducha Świętego, Watykan, 1992.

Budakowska E., Współczesne migracje a nowe wyzwania, [w:] Tożsamość bez granic. Współczesne wyzwania, red. E. Budakowska, Warszawa 2005.

Dudek D., Leczenie depresji, [w:] XXXI Zimowa Szkoła Instytutu Farmakologii PAN - Streszczenie wykładów, red. M. Papp, Kraków 2014.

Frossard A., Nie lękajcie się. Rozmowy z Janem Pawłem II, Watykan 1982.

Heitzman J., Wojnar N., Zaburzenia i choroby afektywne, [w:] Psychiatria, red. J. Heitzman, Warszawa 2007.

Hejnicka-Bezwińska T., Pedagogika ogólna, Warszawa 2008.

Kępiński A., Poznaj siebie, Kraków 2003.

Kramer P. D., Czym jest depresja, Poznań 2007.

Nowak A. J., Psychologiczny aspekt nadziei, [w:] Nadzieja w postawie ludzkiej, red. W. Słomka, Lublin 1992 (Homo Meditans, 7).

Siwek M., Diagnostyka i psychopatologia depresji, [w:] XXXI Zimowa Szkoła Instytutu Farmakologii PAN - Streszczenie wykładów, red. M. Papp, Kraków 2014.

Żółkowska T., Społeczna (de)waloryzacja roli osoby niepełnosprawnej, [w:] Człowiek z niepełnosprawnościa w rezerwacie przestrzeni publicznej, red. Z. Gajdzica, Kraków 2013.

Magdalena Świgost, Nie ma ciemności bez gwiazdy - zmagania o nadzieję człowieka współczesnego, [w:] Nadzieja. Nagrodzone i wyróżnione prace konkursowe, red. Katarzyna Dybeł, Zofia Zarębianka, Kraków 2015, s. 3-15 (Dni Jana Pawła II).

http://dx.doi.org/10.15633/9788374384650.01 